
S
Anais do III Simpósio de Bioquímica e Biotecnologia
Trabalho Completo apresentado na seção: PÔSTER

\title{
IIISIMBBTEC
}

\section{IDENTIFICAÇÃO E CLONAGEM DE PROMOTORES RAIZ-ESPECIFICOS DE EUCALIPTO}

\author{
Renata Lúcia Grunennvaldt ${ }^{1}$, Daniele Cristina Kael ${ }^{2}$, Juliana Degenhardt ${ }^{3}$, Marguerite \\ Quoirin', Isabel Rodrigues Gerhardt ${ }^{3,4}$ \\ ${ }^{1}$ Universidade Federal do Paraná \\ Curitiba - Paraná - E-mail: regrunennvaldt@gmail.com \\ Universidade Tuiuti do Paraná \\ Curitiba - Paraná \\ ${ }^{3}$ EMBRAPA Florestas \\ Colombo - Paraná \\ ${ }^{4}$ UMIP GenClima \\ Campinas - SP
}

\begin{abstract}
RESUMO
A utilização de promotores tecido-específicos é uma das principais estratégias para direcionar a expressão de transgenes a determinados órgãos ou tipos celulares. Por isso, o objetivo deste trabalho foi a clonagem de promotores raiz-específicos, a partir de dados de RNA-Seq obtidos de bibliotecas de raiz, xilema e folha de eucalipto. Dois genes com padrão de expressão preferencial em raiz foram inicialmente selecionados para isolamento da região promotora. Fragmentos de $1 \mathrm{~kb}$ foram clonados em vetor binário pCAMBIA2301, fusionados ao gene repórter da beta-glucuronidase (GUS), para transformação de Populus tremula x Populus alba via Agrobacterium tumefaciens.
\end{abstract}

Palavras-chave: promotor raiz-específico; eucalipto; GUS

\section{INTRODUÇÃO}

Uma das estratégias para obtenção de plantas com características desejadas é a introdução de genes de interesse via transformação genética. Tecnologias transgênicas permitem a incorporação de genes capazes de alterar e aprimorar características de interesse econômico, como alta produção de biomassa, resistência a doenças e qualidade da madeira em espécies florestais, de maneira rápida e com a mínima alteração do genoma. ${ }^{1}$

A identificação e caracterização de promotores órgão-específicos ou estímulodependentes representa uma prioridade entre as ferramentas moleculares. Os promotores podem ser usados em construções gênicas que visam à produção de variedades comerciais, nas quais a expressão generalizada do transgene na planta muitas vezes não é desejada. ${ }^{2}$

O objetivo deste trabalho foi isolar e clonar promotores raiz-específicos de Eucalyptus spp., visando seu uso em construções gênicas para a geração de plantas transgênicas tolerantes a estresses abióticos.

\section{MATERIAL E MÉTODOS}

As estratégias de RNA-Seq e análise de expressão diferencial de genes foram utilizadas para avaliar as sequências produzidas a partir de bibliotecas de cDNA de raiz, caule e folha de 


\section{Anais do III Simpósio de Bioquímica e Biotecnologia Trabalho Completo apresentado na seção: PÔSTER}

IIISIMBBTEC

diferentes genótipos de eucalipto. Dois genes com expressão preferencial em raiz foram selecionados, dos quais amplificou-se $1 \mathrm{~kb}$ da região promotora a partir do DNA extraído de folha de eucalipto pelo método $\mathrm{CTAB}^{3}$. As regiões amplificadas foram clonadas primeiramente em plasmídeo pGEM-T Easy (Invitrogen) para posterior inserção no plasmídeo pCAMBIA2301, vetor binário de transformação de plantas que contém o gene repórter GUS, a partir de sua digestão com as enzimas de restrição EcoRI e BghI.

\section{RESULTADOS E DISCUSSÃO}

A fim de otimizar as condições para isolar a região promotora dos genes selecionados, reações de PCR em gradiente foram realizadas, testando-se diferentes temperaturas de anelamento. De acordo com a Figura 1, observa-se que a melhor temperatura foi a de $62^{\circ} \mathrm{C}$, na qual obteve-se a amplificação das regiões promotoras dos dois genes, com menor produção de bandas inespecíficas.

Figura 1: Gel de agarose 1\% das reações de PCR em gradiente, mostrando as diferentes temperaturas de anelamento utilizadas. 1: Promotor A; 2: Promotor B.

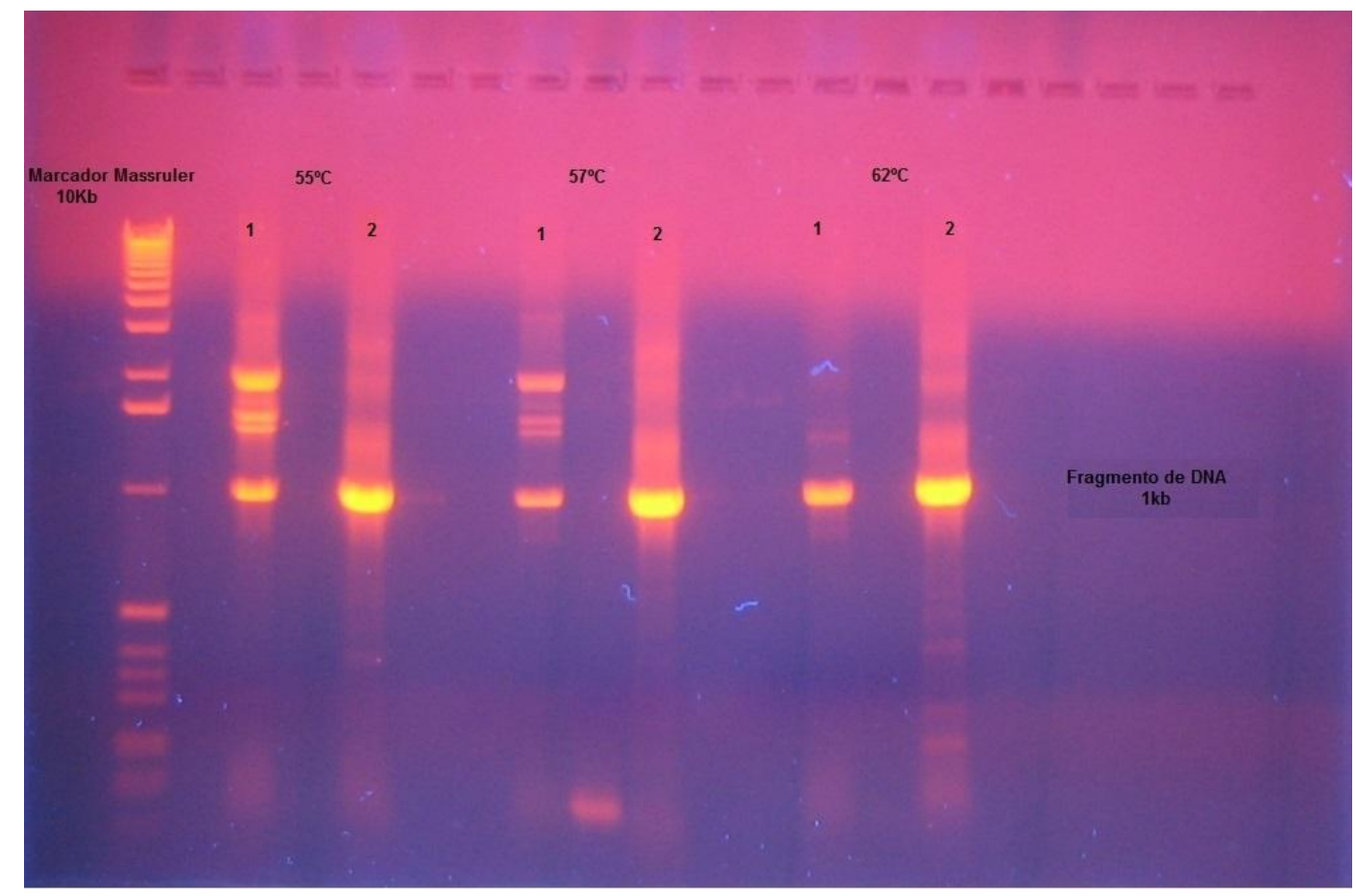

Depois de amplificadas, as regiões promotoras (com sítios de restrição EcoRI e Bg/I flanqueando as extremidades dos fragmentos) foram clonadas em vetor pGEM-T Easy para posterior inserção no plasmídeo pCAMBIA2301. O plasmídeo pCambia2301 é um vetor binário que apresenta o gene de seleção de plantas NPTII (resistência ao antibiótico canamicina) e também o gene repórter UIDA (GUS) sob o controle do promotor constitutivo 35S. Para liberar 0 fragmento correspondente à região do promotor $35 \mathrm{~S}$ e, dessa forma, permitir que a região promotora específica de raiz seja inserida no seu lugar, o pCAMBIA2301 foi digerido com as enzimas de restrição EcoRI e Bghl. 


\section{Anais do III Simpósio de Bioquímica e Biotecnologia Trabalho Completo apresentado na seção: PÔSTER}

\section{IIISIMBBTEC}

$O$ vetor pGEM-T Easy, contendo as regiões promotoras específicas de raiz, foi digerido com as mesmas enzimas EcoRI e BgII, a fim de liberar o fragmento de $1 \mathrm{~Kb}$. Conforme observa-se na Figura 2 houve a liberação do fragmento de $1 \mathrm{~kb}$ referente à região promotora dos dois genes selecionados.

Figura 2: Gel de agarose 0,7\% da digestão do pGEM-T Easy com as enzimas de restrição EcoRI e $B g \Lambda \mathrm{I}$, para liberação do fragmento de $1 \mathrm{~kb}$ correspondente a região promotora específica de raiz. 1: Promotor $A$; 2: Promotor $B$.

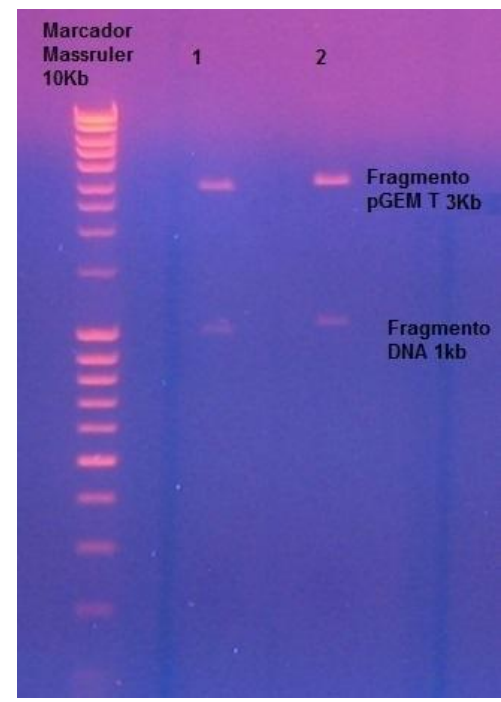

O plasmídeo pCAMBIA2301 e as regiões promotoras específicas de raiz foram utilizados na reação de ligação. O vetor contendo o inserto foi então utilizado diretamente para transformação de $E$. coli TOP 10, por eletroporação. As colônias selecionadas tiveram o DNA plasmidial isolado e digerido com as enzimas de restrição EcoRI e Bg/ll, para a confirmação da inserção da região promotora. Após sequenciamento, os vetores serão usados na transformação de Populus tremula x Populus alba via Agrobacterium tumefaciens.

\section{CONCLUSÕES}

Os objetivos originalmente propostos (isolamento das regiões promotoras e construção de um cassete de expressão contendo os promotores específicos de raiz em fusão com gene repórter GUS) foram alcançados, o que permitirá a transformação de plantas de Populus via Agrobacterium tumefaciens para comprovação da tecido-especificidade dos promotores isolados.

\section{REFERÊNCIAS}

(1) GONZÁLEZ, E. R. Transformação genética de Eucalyptus grandis e do híbrido E.grandis $\mathbf{x}$ urophylla via Agrobacterium. 2002. 107f. Tese (Doutorado em genética e melhoramento de plantas) Escola Superior de Agricultura Luis de Queiroz, Universidade de São Paulo, Piracicaba. 


\section{Anais do III Simpósio de Bioquímica e Biotecnologia Trabalho Completo apresentado na seção: PÔSTER}

\section{IIISIMBBTEC}

(2) RIBEIRO, C.L. Caracterização molecular de um promotor raizespecífico de eucalipto. 2009. 53f.Trabalho de Conclusão (Bacharelado de Botucatu, Botucatu.

Ciências Biológicas) - Universidade Estadual Paulista, Instituto de Biociências

(3) Chang S., Puryear J., Cairney J. A simple and efficient method for isolating RNA from pine trees. Plant Molecular Biology Reporter 11: 113-116. 1993. 